\title{
The impact of principal administration on elementary school teachers' performance
}

\author{
Liza Krisdiani ${ }^{*}$ \\ Riswandi $^{2}$ \\ Rochmiyati ${ }^{3}$ \\ 1,2,3 Master Program in Primary School Teacher Education, University of Lampung, Bandar Lampung, Indonesia
}

\begin{abstract}
The problem in this research is related to the principal's management of the performance of educators. This study is intended to explore how principals should work in schools. Six efforts that can be made by principals to improve teacher performance include: (1) focus and be serious on efforts to improve teacher competence, (2) provide adequate funds to improve teacher professionalism, (3) supervise and guide teachers professionally, (4) create a comfortable school organizational culture for teachers, (5) create innovation and progress in schools, and (6) provide various awards for every achievement made by teachers. Principals are thus advised to be more active and creative in collaborating with teachers and stakeholders in teacher performance education. This study adopted a quantitative research method to see the partial effect between the variables in the survey with a quantitative approach. The population and sample of this study were elementary school teachers at SDN 1 Sumber Agung, Kemiling Sub District, Bandar Lampung City. Data was collected by referring to non-test techniques (Observation, interviews, and documentation) and test techniques (Questionnaire). The data analysis technique was carried out using instrument validity test, instrument reliability test, instrument difficulty level, and differentiating power.
\end{abstract}

\section{KEYWORDS}

Management; school principal; teachers

Received: 2 August 2021

Accepted: 14 August 2021

Published: 20 August 2021

\section{Introduction}

The quality of education is largely determined by the learning process in educational institutions (Lumban Gaol, 2017), including schools. Principals and teachers are the main movers who have a significant effect on each implementation of the student learning process while in the school environment. Without good teacher performance and an adequate role for school principals in managing schools, it will be very difficult to improve the quality of education or achieve national education standards. It is stated in the Law on the National Education System Number 20 of 2003, Chapter IX Article 35 paragraph 1 regarding the eight components of the National education standard. These components consist of content, process, competence of graduates, education staff, facilities and infrastructure, management, financing, and educational assessment. These eight components must be improved in a planned and periodic manner to obtain fundamental changes. To achieve these eight components of national education, the quality of the learning process in schools is the determinant.

Learning in schools will be successful if the principal can manage and lead the school well. The ability of the principal in managing and leading the school is shown by the leadership he has to make the school a place for effective and efficient learning.

In essence, leadership plays a very important management role and functions as a determinant of the success of any group or organization (Okoroji, Anyanwu \& Ukpere, 2014). The same thing was stated by Igwe and Odike (2016) who emphasized that just like other organizations, school success and failure are very much closely related to the leadership quality possessed by school principals. Therefore, schools as educational organizations must be led by principals who can function their leadership management properly. Tan (2016) stated that the principal as an educational leader has four functions, namely (1) creating the organization to promote collaborative decision-making processes among multiple stakeholders, and (2) managing the teaching-learning program (3) establishing an academic school vision and providing guidance, (4) Educator development and comprehension. 
The principal's management job is undoubtedly complicated. Principals, in particular, must be able to improve teacher performance in addition to managing schools to be successful and efficient. Susanto (2016) states that improving teacher learning performance can be accomplished if the principle, as a leader, can motivate teachers in his school to work hard and dedicate themselves to the goal at hand. Teachers will never perform at their best if they do not receive appropriate support from their principal in order to improve their performance. In this situation, the teacher's job include maximizing each student's potential through education, training, guidance, and development. As a result, if efforts are made to develop the role of school principals as educational leaders, the quality of teacher performance can be improved and enhanced

Currently, efforts to improve teacher performance in Indonesia are urgently needed. The low performance of teachers is an indication of the low ability of school principals in carrying out their management roles as educational leaders. As a result, these conditions not only impact teachers but also students. The potential of students, in this case, is not explored and developed to the fullest.

Based on data published by the Organization for Economic Co-operation and Development (OECD) in 2015, it was reported that: "Principals in Indonesia need support to develop the skills that will enable them to play their role in managing teacher induction, performance assessments and appraisals. ; the monitoring, promoting, and sanctioning of teachers; the dissemination of information about teacher performance; and accountability for overall school performance." The conditions expressed by the OECD indicate that school principals have not been able to carry out their role as principals well in Indonesia so that it has an impact on the low performance of teachers. Sumintono, Sheyoputri, Jiang, Misbach, and Jumintono (2015) suggest that the preparation and development of principals' leadership are very important considering the fundamental functions of principals related to improving schools and the education system. In addition, Susanto (2016) added that the role of the principal is very influential in the school environment, especially for teaching staff or teachers. The results of the study by Supovitz, Sirinides, and May (2010) show how important the principal's work is in student learning because it indirectly affects teacher activities through increased collaboration and communication during teaching.

Based on the above problems, this study seeks to contribute to increasing knowledge about the role that must be carried out by school principals to create teacher performance improvements through the roles that can be performed by school principals. Therefore, the formulation of the problem in this study is "What role should the principal play so that teacher performance can improve when managing educational institutions (schools)?

This paper is intended to explore the importance of principal management on teacher performance. This study also aims to describe the efforts that must be made by school principals so that teacher performance can improve. This paper will contribute both theoretically and practically. Theoretically, this paper will increase knowledge about the role of school principals in improving teacher performance. Meanwhile, practically, this can increase the knowledge of principals on how they should carry out their role as educational leaders in schools. Through the results of this study, both the local government and the central government will be helped to improve the professionalism of teachers and the role of school principals.

\section{Methods \\ Research methods}

The method used in this study is a quantitative research method that aims to see the effect of the existing variables partially (Sugiyono, 2014). The purpose of this quantitative research is to show the relationship between variables. This type of research is a correlational description considering the aim is to describe the relationship between factors or as a variable that affects the situation without manipulating the variable (Sugiyono, 2016). This study aims to examine the principal's management (variable X1) on the performance of elementary school teachers (variable Y).

\section{Population and sample}

The population and sample of this study were elementary school teachers at SDN 1 Sumber Agung, Kemiling Sub District, Bandar Lampung city. Data was collected by referring to non-test techniques (Observation, interviews, and documentation) and test techniques (Questionnaire). The data analysis technique used instrument validity test, instrument reliability test, instrument difficulty level, and differentiating power.

\section{Results and discussion}

The role of the principal as a school leader is closely related to the various tasks he carries out, for example as administrator, manager of various resources in the school, and teaching leader. Principals who serve as functional staff must have professional competence as school leaders. Referring to the Decree of the Minister of State Apparatus 
Control Number 296 of 1996 concerning the Position of Teachers, it is stated that the principal is a teacher who has additional duties.

In other words, the principal must have managerial and leadership skills to make the school he leads becomes an effective and efficient educational institution in carrying out the learning process. In other words, schools as learning centers must be qualified under the optimal leadership of the principal. In improving the quality of schools, the principal's leadership is the most important component in making decisions related to various activities in schools (Yunus, Andari \& Islam, 2017).

Despite the fact that the principle has such a wide range of responsibilities, attempts to improve teacher effectiveness must be made. Principals should pay more attention to teaching leadership and make various initiatives. The principal's function as a teaching leader, who is a model, coach, facilitator, and mentor rather than a guardian or teacher of teaching, is to blame for this situation (Bredeson \& Johansson, 2000). That is, when the principal enters into the classroom to supervise the teaching of instructors, he or she may not serve as an evaluator or judge. School principals must follow the five fundamental principles listed below when carrying out their supervisory responsibilities; (1) collegial, not hierarchical, consultative connection, (2) democratically implemented, (3) teachercentered, (4) needs-based, and (5) professional help available (Mulyasa, 2005).

Bredeson and Johansson (2000) found four important areas that have an impact on teacher teaching in schools that principals need to do, namely: (1) principals as teaching leaders, (2) principals as creators of the learning environment, (3) principals directly involved in designing, delivering and determining the content of teacher professional development, and (4) principals assessing the results of teacher professional development. These four areas can be implemented well by the principal if the principal understands and carries out his roles and responsibilities wholeheartedly.

In the context of education, the principal is a key figure for school success (Suhardiman, 2012; Wiyono, 2017). The progress or decline in the quality of learning in schools is influenced by the quality of management carried out by the principal. The more adequate the understanding of the principal in carrying out his management role as the principal, the teacher performance and the quality of learning, in general, will tend to improve.

In addition to being a catalyst and mediator in translating central government policies, school principals must also be able to convey the aspirations of school residents or stakeholders to the government. The aim is to create policy conformity with the reality on the ground. Without appropriate action by the principal to bridge this, the condition of the school will tend to be static or not progressing.

Principal management of teacher performance is very important. The principal must focus more on paying attention to activities that seek to improve and improve the quality of learning through improving the performance of the teachers he handles (Susanto, 2016). The results of the study from Emmanouil, Osia, and Paraskevi-Ioanna (2014), stated that the principal's leadership is a mediator who generates inspiration, motivation, support, and guidance to lead to the birth of the maximum potential of teachers and the achievement of improving school quality. The results of Hasan's (2017) study show that the principal's leadership affects teacher performance.

In essence, the concept of performance is more focused on the ability of individuals to carry out their duties and responsibilities to achieve organizational goals (Siburian, 2014; Pangaribuan, Siburian, Manullang, 2016). Pangaribuan (2016) states that performance leads to an assessment of the knowledge, attitudes, and behavior in work that is oriented to quantity, quality, and accountability following the established work standards. From this understanding, it can be said that performance includes cognitive, affective, and psychomotor that a person has in doing the tasks that have been given.

Arman, Thalib, and Manda (2016) stated that teacher performance is a presentation of the work done by teachers in carrying out their duties as professional educators. A broader definition is conveyed by Igwe and Odike (2016) who explain that teacher performance can be described as tasks carried out by teachers at the time given school to achieve daily school goals, class goals, and all educational goals and objectives. . Teacher performance, in other words, include tasks that are done based on the tasks given at school.

The various duties or responsibilities of the teacher in this case, of course, require the support of the principal in carrying out their duties and responsibilities. If the principal does not give serious attention to the performance of the teacher, the teacher will face difficulties in completing the various tasks he carries. Therefore, improving teacher performance can be carried out by school principals (Hasan, 2017) as part of the role that education leaders must carry out to improve the quality of learning in schools. The importance of improving teacher performance as a component of improving the quality of learning in schools is in line with the view of Anugraheni, (2017) which states that improving teacher performance can be developed through teacher competency training. Management of teacher performance can be done by the principal by improving teacher competence. Teacher competence is a skill or ability that must be possessed by a teacher to carry out various tasks. The Regulation of the Minister of National Education of the Republic of Indonesia Number 16 of 2007 which contains Academic Qualification Standards and Teacher Competencies states that every teacher is required to have four main competencies, namely pedagogic, personality, social, and professional. The better teacher competence will be in line with the better teacher performance. Thus, 
based on the principal's management role, six efforts can be made by school principals to improve teacher performance as follows:

First, principals must have a high commitment to school improvement and focus on curriculum development as well as facilitating and supporting teachers in developing their competencies (Hermino, 2016). Efforts that can be made by the head to improve teacher performance are by directing teachers to always take part in education and training activities to improve their competence, for example, through participation in seminars or workshops. Hosnan (2016) stated that training tailored to the competence of each teacher is needed as an effort to improve teacher competence. Furthermore, Mulyasa (2005) suggested that the teacher's performance improvement can be done by involving teachers in the activities of the Subject Teacher Deliberation Forum (MGMP), Teacher of Guidance Deliberation Forum (MGP), and Teacher Working Groups (KKG).

Second, the management that can be done by the principal on teacher performance can also be in the form of an effort to allocate a budget to increase teacher competence (Hermino, 2016). The principal must be able to prepare a budget that is following the needs of the school, including the need for teacher professional development. By optimizing funds for teacher competency development, the education and training process, as well as activities related to teacher professional development, can run smoothly. Efforts that can be made by school principals to strengthen funding in improving teacher performance are to apply for financial assistance to the government and private parties. Third, the principal can provide advice and guidance to teachers on their performance in carrying out the learning process (Hermino, 2016). That is, when teachers face various obstacles in learning, the principal must assist to be able to solve the learning problems faced. Assistance to teachers that can be provided by the principal can be in the form of providing clinical supervision or further training for teachers.

Fourth, the principal must create a conducive school organizational culture so that the performance of teachers and education personnel are not disturbed. Principals must also be able to create an organizational culture in schools as conducive as possible to improve student learning achievement and teacher performance (Lumban Gaol, 2017). Susanto (2016) concluded that organizational culture is the rules of the game or reference (values, norms, philosophy, and beliefs) of a particular organization or community that is understood by all members of the organization which is manifested in an internally integrated mindset and behavior characterized by with external adaptation to achieve organizational goals. Furthermore, Wibowo (2016) states that the performance of human resources is largely determined by the internal and external environmental conditions of the organization, including organizational culture. The comfortable feeling experienced by teachers will increase their motivation, commitment, and loyalty in doing the tasks they carry out (Hasan, 2017). Thus, principals have a vital role so that they are required to be able to create an organizational culture and a conducive work climate in schools.

Fifth, principals can create reforms, comparative advantages, and take advantage of various opportunities so that the learning process can take place properly. Sixth, giving awards for the achievements of teachers must become a culture in schools. In other words, the principal, in this case, must pay serious attention to the achievements that have been championed by the teacher. These are the six roles of the principal as a solution for improving teacher performance in schools. Although this is not so easy to do, school principals can work together with education stakeholders to achieve school goals.

\section{Conclusion}

The principal is an educational leader who plays an important role in efforts to improve teacher performance. Management efforts that can be made by school principals on teacher performance related to their role as educational leaders in schools include the following: (1) maximizing focus on improving teacher competence, (2) allocating adequate budgets for increasing teacher professionalism, (3) providing professional advice and guidance to teachers, (4) creating a conducive school organizational culture; (5) create renewal and excellence, and (6) provide rewards for teachers who perform well.

Thus, the principal must make the school a place of learning for every school member so that a conducive learning process can be obtained. The principal must also be able to become a figure who can protect teachers so that teachers feel that the work they do is appreciated. However, the limitations of school principals in carrying out their role in improving teacher performance require more serious efforts from the local government (Education authorities) and the central government (Ministry of Education and Culture) in terms of facilitating school principals. Support from local and central governments is very important in improving the role of principals and teacher performance in schools.

\section{References}

Anugraheni, I. (2017). Analisa faktor-faktor yang mempengaruhi proses belajar guru-guru sekolah dasar. Kelola: Jurnal Manajemen Pendidikan. 4(2), 205-212. 
Arman, A., Thalib, S. B., \& Manda, D. (2016). The effect of school supervisors competence and school principals competence on work motivation and performance of junior high school teachers in Maros Regency, Indonesia. International Journal of Environmental and Science Education. 11(15), 7309-7317.

Bredeson, P. V. \& Johannson, O. (2000). The school principal's role in teacher professional development. Journal of in-service education, 26(2), 385-401.

Depdiknas. (2003). Undang-undang RI No.20 tahun 2003.tentang sistem pendidikan nasional.

Emmanouil, K., Osia, A., \& Paraskevi-Ioanna, L. (2014). The impact of leadership on teachers' effectiveness. International Journal of Humanities and Social Science. 4(7), 34-39.

Hasan, M. N. (2017). Influence of work motivation, leadership and organizational culture principal of the teacher performance in vocational school (SMK) Muhammadiyah, Rembang City, Central Java Province, Indonesia. European Journal of Business and Management. 9(2), 36-44.

Hermino, A. (2016). Manajemen kemarahan siswa, kajian teoritis dan praktis dalam manajemen pendidikan. Yogyakarta: Pustaka Pelajar.

Himpunan Peraturan Perundang- undangan Sisdiknas. (2010). Sistem pendidikan nasional. Bandung: Fokus Media.

Hosnan, M. (2016). Etika profesi pendidik: Pembinaan dan pemantapan kinerja guru, kepala sekolah, serta pengawas sekolah. Bogor: Ghalia Indonesia.

Igwe, N. N., \& Odike, M. N. (2016). A survey of principals' leadership styles associated with teachers' job performance in public and missionary schools in Enugu State Nigeria. British Journal of Education, Society and Behavioural Science. 17(2), 1-21.

Lumban Gaol, N. T. (2017). Teori dan implementasi gaya kepemimpinan kepala sekolah. Kelola: Jurnal Manajemen Pendidikan. 4(2), 213-219.

Mulyasa, E. (2005). Menjadi kepala sekolah profesional dalam konteks menyukseskan MBS dan KBK. Bandung: PT Pemaja Rosdakarya.

OECD/Asian Development Bank. (2015). Reviews of national policies for education/ education in Indonesia: Rising to the challenge. Paris: OECD (Organization for Economic Co- operation and Development) Publishing.

Okoroji, L. I., Anyanwu, O. J., \& Ukpere, W. I. (2014). Impact of leadership styles on teaching and learning process in imo state. Mediterranean Journal of Social Sciences. 5(4), 180-193.

Republik Indonesia. (2007). Permendiknas no.16 tahun 2007 tentang standar kualifikasi akademik dan kompetensi guru. Jakarta: Seketariat Negara.

Pangaribuan, W., Siburian, P. \& Manullang, J. (2016). Determining factors of senior high school principals' performance in Medan. International Journal Basic and Applied Research (IJSBAR). 25(2), 44-57

Siburian, Paningkat. (2014). Determinant factors of organizational commitment of elementary school teachers in North Sumatra Indonesia. International Journal of Sciences: Basic and Applied Research (IJSBAR). 18(1), 208-220.

Suhardiman, Budi. (2012). Studi pengembangan kepala sekolah konsep dan aplikasi. Jakarta: Rineka Cipta.

Sugiyono. (2014). Metode penelitian pendidikan pendekatan kuantitatif, kualitatif, dan R\&D. Bandung: Alfabeta.

Sugiyono. (2016). Metode penelitian kuantitatif, kualitatif dan R\&D. Bandung: PT Alfabet.

Sumintono, B., Sheyoputri, E. Y. A., Jiang, N., Misbach, I. H. \& Jumintono. (2015). Becoming principal in Indonesia: Possibility, pitfalls and potential. Asia Pasicific Journal of Education, 1-11.

Supovitz, J., Sirinides, P., \& May, H. (2010). How principals and peers influence teaching and learning. Journal of Educational Administration Quarterly. 46 (1), 31-56.

Susanto, Ahmad. (2016). Teori belajar dan pembelajaran. Jakarta: Prenada Media Group.

Tan, C. Y. (2016). Examining school leadership effects on student achievement: The role of contextual challenges and constraints. Cambridge Journal of Education, 48(1).

Wibowo. (2016). Manajemen kinerja, edisi kelima. Jakarta: PT Rajagrafindo Persada.

Wiyono, B. B. (2017). The effect of self- evaluation on the principals' transformational leadership, teachers' work motivation, teamwork effectiveness, and school improvement. International Journal of Leadership in Education. 21(1).

Yunus, M., Andari, K. D. W., \& Islam, M. A. (2017). The principal's competences in implementing cultural and environmental management of the school in SDN 033 Tarakan. JPI (Jurnal Pendidikan Indonesia). 6(2), 263-274. 